\title{
Consequences of the electronic tuning of latent ruthenium- based olefin metathesis catalysts on their reactivity
}

\author{
Karolina Żukowska*1, Eva Pump ${ }^{2}$, Aleksandra E. Pazio ${ }^{3}$, Krzysztof Woźniak $^{3}$, \\ Luigi Cavallo 4 and Christian Slugovc ${ }^{*}$
}

\author{
Full Research Paper \\ Address: \\ ${ }^{1}$ Institute of Organic Chemistry, Polish Academy of Sciences, \\ Kasprzaka 44/52, 01-224 Warszawa, Poland, ${ }^{2}$ Institute of Chemistry \\ and Technology of Materials, Graz University of Technology, NAWI \\ Graz, Stremayrgasse 9, $8010 \mathrm{Graz}$, Austria, ${ }^{3}$ Biological and Chemical \\ Research Centre, Faculty of Chemistry, University of Warsaw, Żwirki \\ Wigury 101, 02-089; Warszawa, Poland and ${ }^{4}$ Kaust Catalysis Center, \\ Physical Sciences and Engineering Division, King Abdullah University \\ of Science and Technology, Thuwal 23955-6900, Saudi Arabia \\ Email: \\ Karolina Żukowska* - karolina.zukowska@gmail.com; \\ Christian Slugovc* - slugovc@tugraz.at \\ * Corresponding author \\ Keywords: \\ DFT calculations; olefin metathesis; ring closing metathesis; \\ ring-opening metathesis polymerisation; ruthenium
}

\begin{abstract}
Two ruthenium olefin metathesis initiators featuring electronically modified quinoline-based chelating carbene ligands are introduced. Their reactivity in RCM and ROMP reactions was tested and the results were compared to those obtained with the parent unsubstituted compound. The studied complexes are very stable at high temperatures up to $140{ }^{\circ} \mathrm{C}$. The placement of an electronwithdrawing functionality translates into an enhanced activity in RCM. While electronically modified precatalysts, which exist predominantly in the trans-dichloro configuration, gave mostly the RCM and a minor amount of the cycloisomerization product, the unmodified congener, which preferentially exists as its $c i s$-dichloro isomer, shows a switched reactivity. The position of the equilibrium between the cis- and the trans-dichloro species was found to be the crucial factor governing the reactivity of the complexes.
\end{abstract}

\section{Introduction}

Olefin metathesis is a catalytic process during which $\mathrm{C}-\mathrm{C}$ double bonds are exchanged [1]. Since the first examples were published in the 1950s, many stunning accomplishments have been made in the field resulting in ever increasing interests in

the method. Establishment of well-defined molybdenum- and ruthenium-based complexes lead to multitude of applications [2-4]. Especially, the latter class of compounds have gained attention due to their user-friendly character caused by a wide 
functional group-tolerance and high oxygen and moisture stability. Although a great progress has been made, the unsuitability of ruthenium complexes for high temperature applications remains one of the greatest challenges in the field.

Modifications in the basic structure of ruthenium-based olefin metathesis catalysts led to a diversification of catalytic profiles (Figure 1) [5,6]. Perhaps the most important one was the introduction of bidentate benzylidene ligands instead of simple alkylidenes, thus giving rise to the class of Hoveyda-type complexes with the parent compound 2 [7]. Further modifications of such systems followed. One of the most common is tuning of the properties of the benzylidene ligand so that modified reactivity of the resulting complex is achieved [8]. Various examples of such approaches have been published over the years. Particularly interesting results were obtained by substituting the oxygen atom with sulfur or nitrogen leading to a group of structurally diverse ruthenium chelates [9-11].

$\mathrm{N}$-Based chelating complexes offer the advantage of a great availability of precursors for amine ligands making the number of possible structures virtually unlimited. Complexes incorporating alkylidene ligands based on aromatic [12-15] or aliphatic amines [16,17] and Schiff base patterns [18-22] have been prepared so far, exhibiting diverse activities ranging from very fast to very slow initiation. Furthermore, in those compounds, a trans-cis isomerization of the chloride ligands was observed in many cases (Scheme 1) [16]. This phenomenon has been widely discussed in literature with multiple reports of superior activity of trans-configured complexes. The general hypothesis is that the trans-dichloro form of the complex promotes metathesis whereas the cis-dichloro form is postulated to be metathetically inactive $[23,24]$. Thus, the trans-cis isomerization can be exploited for slowly releasing the olefin metathesis active species $[25,26]$.<smiles></smiles>

trans-5a

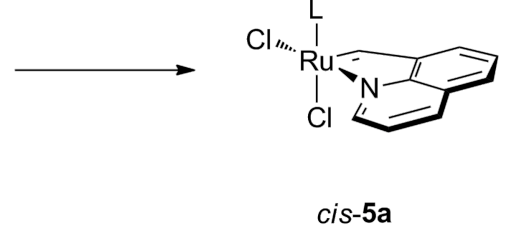

cis-5a

\section{Scheme 1: trans-cis Isomerization.}

Aside from the interesting conformational behavior, nitrogenchelated complexes possess some practical properties, namely they tend to be thermally stable, enabling applications at elevated temperatures. Being aware of the various advantages of such systems, we set out to study substituted quinolone-ruthenium chelates in view of their trans-cis susceptibility and its consequences.

\section{Results and Discussion Synthesis and characterization}

The shortest pathway to obtain the desired ligands was chosen to provide access to starting materials. It was envisioned as a two-step sequence of triflation of commercially available substituted 8-hydroxyquinolines 8 and $\mathbf{9}$ followed by a Suzuki coupling as shown in Scheme 2 [14].

The cyano-substituted compound $\mathbf{1 0}$ was obtained without difficulty, but esterification of compound $\mathbf{9}$ was problematic

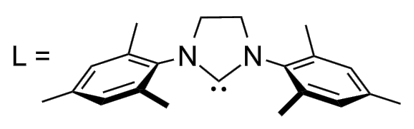<smiles></smiles>

1<smiles>CC(C)Oc1ccccc1C=[Te](Cl)(Cl)Cl</smiles>

2<smiles>Cl[R]1(Cl)CCc2cccnc2N1</smiles>

3

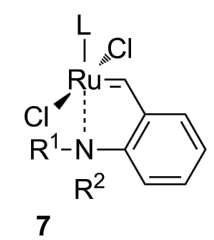

a $\mathrm{R}^{1}=\mathrm{Bn}, \mathrm{R}^{2}=\mathrm{H}$

b $\mathrm{R}^{1}=\mathrm{Et}, \mathrm{R}^{2}=\mathrm{Ph}$

c $\mathrm{R}^{1}=\mathrm{R}^{2}=\mathrm{Et}$ 
<smiles></smiles>

$$
\text { 8, } \mathrm{R}=\mathrm{CN}
$$$$
\text { 9, } \mathrm{R}=\mathrm{CHO}
$$<smiles>[R]c1ccc2cccc(O[Tl])c2n1</smiles>

$10, \mathrm{R}=\mathrm{CN}, \quad 84 \%$

$11, \mathrm{R}=\mathrm{CHO}, 60 \%$

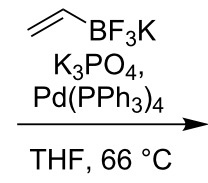<smiles>[R]c1ccc2cccc(C=C)c2n1</smiles>

$12, \mathrm{R}=\mathrm{CN}, \quad 88 \%$

$13, \mathrm{R}=\mathrm{CHO}, 82 \%$

Scheme 2: Synthesis of the ligand precursors.

because of purification issues (cf. Supporting Information File 1) so an alternative pathway was established. Starting from 2-bromoaniline upon Doebner-Miller reaction and oxidation, we obtained the corresponding bromide derivative which was subsequently converted via Suzuki coupling into the carbene precursor 13. Both compounds $\mathbf{1 2}$ and $\mathbf{1 3}$ were then used in a carbene exchange reaction with compound $\mathbf{1}$ conducted in toluene at $80{ }^{\circ} \mathrm{C}$ (see Scheme 3), releasing the desired complexes $\mathbf{1 4}$ and $\mathbf{1 5}$ as trans-dichloro isomers in good yields.

Based on the previously reported trans-cis isomerization of the parent quinoline-based complex $\mathbf{5 a}$, a potential isomerization of 14 and $\mathbf{1 5}$ was investigated. Reaction conditions for the isomerization of $5 \mathbf{a}$ (complete isomerization after 6 days at $23{ }^{\circ} \mathrm{C}$ in $\mathrm{CD}_{2} \mathrm{Cl}_{2}$ ) [14] were proven to be ineffective for the isomerization of $\mathbf{1 4}$ and $\mathbf{1 5}$, so that more forcing conditions were applied: Compounds $\mathbf{5 a}, 14$ or 15 were dissolved in $\mathrm{CDCl}_{3}$ and heated to $140{ }^{\circ} \mathrm{C}$ for $1 \mathrm{~h}$ in a microwave reactor.

When the reactions were performed in air, only decomposition of the complexes was observed. Upon using oxygen-free conditions a complete rearrangement of trans-5a to cis-5a in $30 \mathrm{~min}$ was obtained. Attempts, to prepare the cis-isomers of electronically modified complexes $\mathbf{1 4}$ and $\mathbf{1 5}$ in a similar fashion, however, turned out to be difficult. Using methods, such as starting from a pyridine containing the ruthenium complex, which is known to increase the cis-content, or increasing the exposure time of the catalyst up to $8 \mathrm{~h}$ in microwave at $140{ }^{\circ} \mathrm{C}$ in $\mathrm{CDCl}_{3}$ resulted in limited success.

The formyl-substituted complex $\mathbf{1 5}$ underwent isomerization, but only a mixture of $11 \%$ cis-15 and $89 \%$ trans $\mathbf{- 1 5}$ was obtained (cf. Supporting Information File 1). In the case of the $\mathrm{CN}$-substituted compound $\mathbf{1 4}$, on the other hand, no evidence for any isomerization could have been retrieved. These results suggest, that the introduction of the electron withdrawing substituent in 2-position changes the thermodynamic equilibrium favoring the trans- over the cis-isomers. In any case, a remarkable thermal stability of all studied compounds was found.

Intrigued by the observed phenomenon, we turned to structural studies. Structures of $\mathbf{1 4}$ and $\mathbf{1 5}$ have been determined using single-crystal X-ray diffraction. Each of them includes two molecules of the studied compound in the trans-conformation and one molecule of the solvent (dichloromethane) in the asymmetric part of the unit cell (Figure 2). Both crystals are isotypic, so the crystal packing is identical and lattice dimensions are very similar (Figure 3).

Bond lengths and angles of 5a, $\mathbf{1 4}$ and $\mathbf{1 5}$ are very similar, so their different tendencies to form the corresponding ciscomplexes could not be rationalized based on this dataset. The 

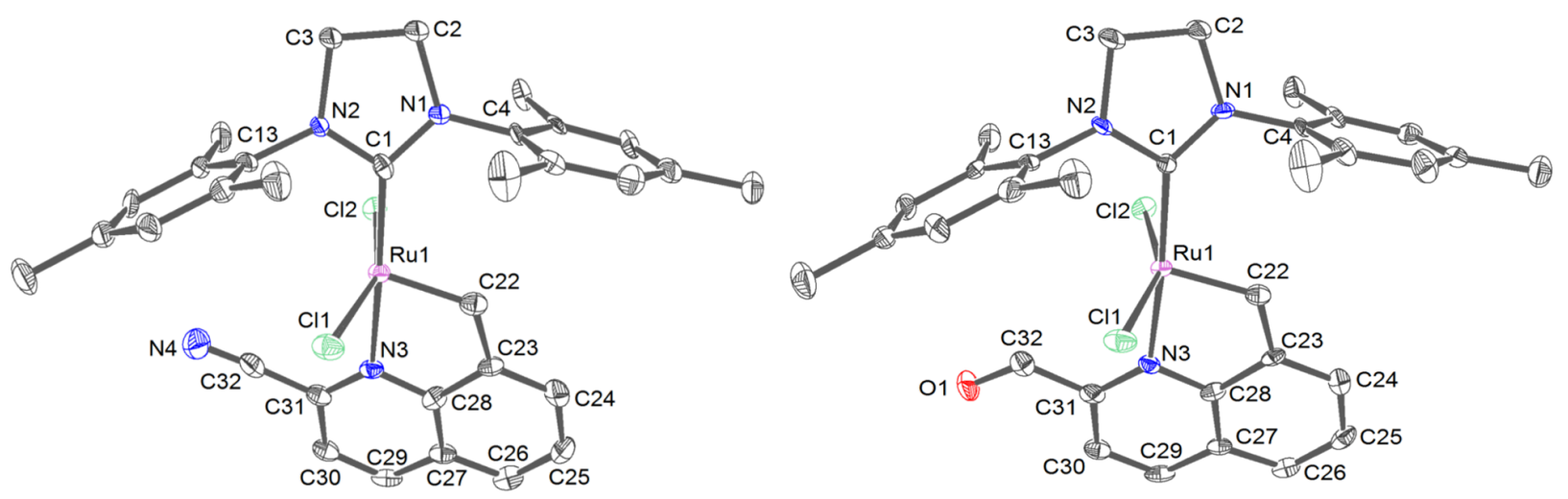

Figure 2: ADPs (atomic displacement parameters) and atoms labeling of the first molecule in the asymmetric part for 14 (left) and 15 (right). Thermal ellipsoids at $50 \%$ level of probability. Hydrogen atoms were omitted for clarity.

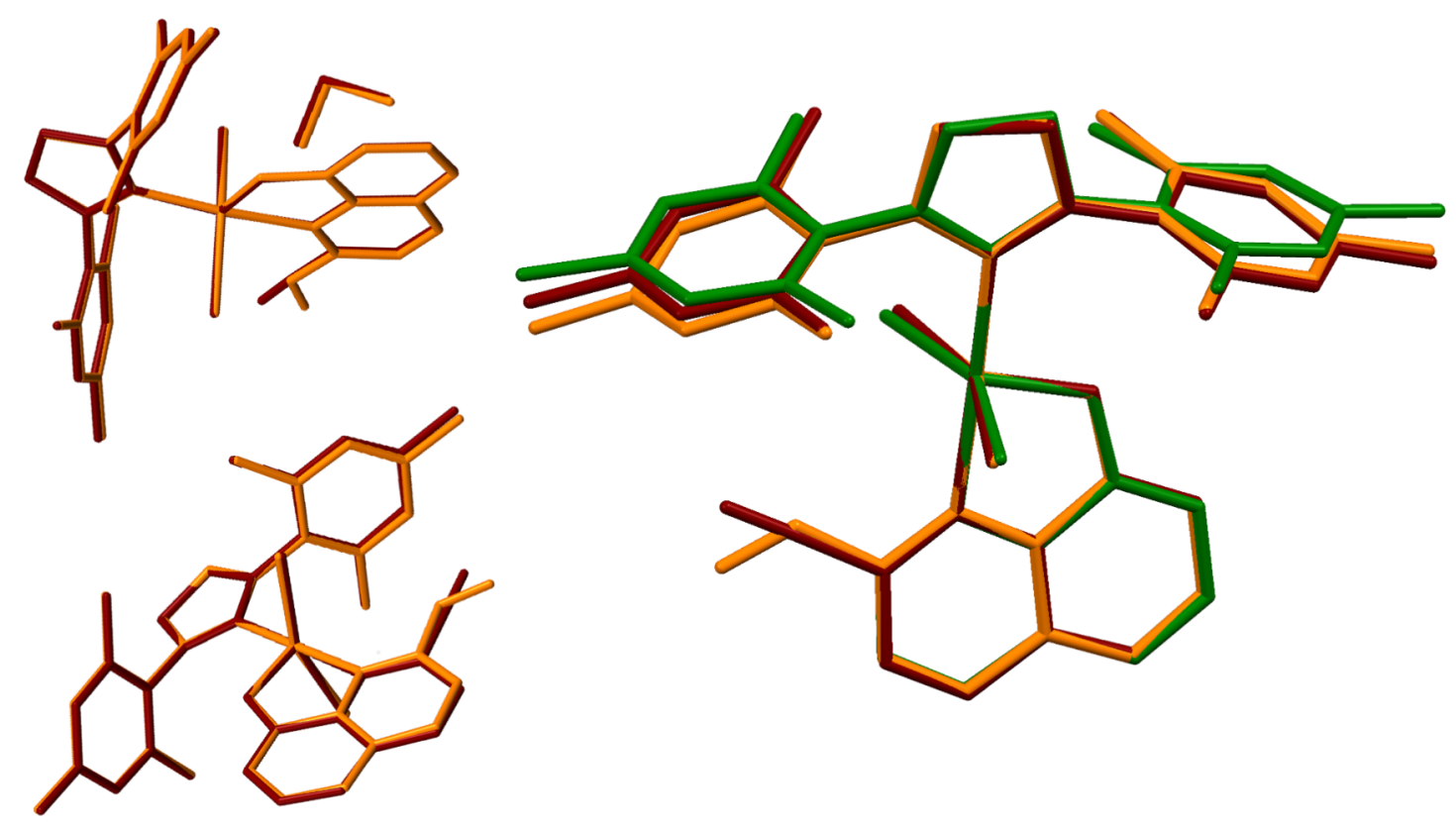

Figure 3: Superposition of the asymmetric parts of units' cells in both investigated structures: an example of isostructural packing (left). Superposition (right side) trans forms of all studied molecules $5 \mathrm{a}$ (green), 14 (ruby) and 15 (orange).

only feature worth mentioning is a slightly decreased $\mathrm{Ru}(1)$ $\mathrm{C}(22)$ bond length in compound $\mathbf{1 5}$ compared to $\mathbf{5 a}$ or $\mathbf{1 4}$ (1.829, 1.845 and $1.842 \AA$, respectively).

\section{DFT calculations}

Density functional theory (DFT) calculations were performed with the aim to learn more about the compounds under investigation especially in view of their peculiar trans-cis isomerization behavior. Geometry optimizations were conducted by BP86//SVP, solvent effects were added by single point calcula- tions using M06//TZVP functional (cf. Supporting Information File 1). The first question tackled concerned the anticipated coordination of the carbonyl group in compound $\mathbf{1 5}$ to form the corresponding 18-electron complex. Formation of the 18-electron compound is in principle feasible although it is endothermic by $2.6 \mathrm{kcal} / \mathrm{mol}$. Thus, it can be concluded that preferably the corresponding 16 -electron species is present in solution. Next, we investigated the relative stabilities of the trans-dichloro versus the cis-dichloro isomers. As already stated in literature, DFT calculations suggested a more preferential 
arrangement of $\mathbf{5 a}$ in the cis-dichloro configuration [23,24]. Here, the equilibrium was investigated assuming solvation in $\mathrm{CH}_{2} \mathrm{Cl}_{2}$ and results revealed a preference for the cis-dichloro isomer in the case of $\mathbf{5 a}$ (cis-5a is $4.1 \mathrm{kcal} / \mathrm{mol}$ more stable than trans-5a) and $\mathbf{1 5}$ (cis-15 is $2.4 \mathrm{kcal} / \mathrm{mol}$ more stable than trans15). In contrast, the cyano-group substituted compound 14 exists preferably in the trans configuration of the chloride ligands (trans-14 is $1.4 \mathrm{kcal} / \mathrm{mol}$ more stable than cis-14). Because the cis isomer is better stabilized in solvents with high dielectric constants (such as $\mathrm{CH}_{2} \mathrm{Cl}_{2}$ ) than in solvents with low dielectric constants [27], the trans-cis energies were calculated in toluene (as an example for a solvent with low dielectric constant). In this case, 5a is still preferably in the cis configuration (cis-5a is $1.3 \mathrm{kcal} / \mathrm{mol}$ more stable than trans-5a), while in $\mathbf{1 4}$ and $\mathbf{1 5}$ the trans configuration is favored (by $0.7 \mathrm{kcal} / \mathrm{mol}$ in case of 15 and $4.2 \mathrm{kcal} / \mathrm{mol}$ in case of 14). Further, the energy profile for the isomerization reaction was investigated taking a dissociative and a concerted pathway into consideration (cf. Figure 4).
As disclosed earlier [23,24], the concerted pathway is the most likely operative for the isomerization of 5a. The transition state TS2 (which is the transition state for the concerted pathway) is $5.3 \mathrm{kcal}$ lower in energy than the transition state for closing the chelating ligand towards the cis-dichloro configured form (TS1 $\left.1_{\text {cis }}\right)$. The energetic preference of the concerted over the dissociative pathway is decreasing when substituents in 2 position of the quinoline ligand are present. For 14 and 15 the transition state for the generation of the catalytically active 14-electron species ( $\mathbf{T S 1} \mathbf{1}_{\text {trans }}$ ) is considerably lower compared to $\mathbf{5 a}$. These results go in hand with studies on electronically modified Hoveyda-type catalysts [28,29] and electronically modified ester-chelating benzylidene complexes [30]. Moreover, as already discussed, TS2 becomes energetically more demanding so that for $\mathbf{1 4}$ and $\mathbf{1 5}$ the pathways for the isomerization (leading to the olefin metathesis inactive cis-dichloro form) becomes less important. Consequently, complex $\mathbf{1 5}$ and in particular 14 should be metathetically more active than their unsubsituted version $\mathbf{5 a}$.

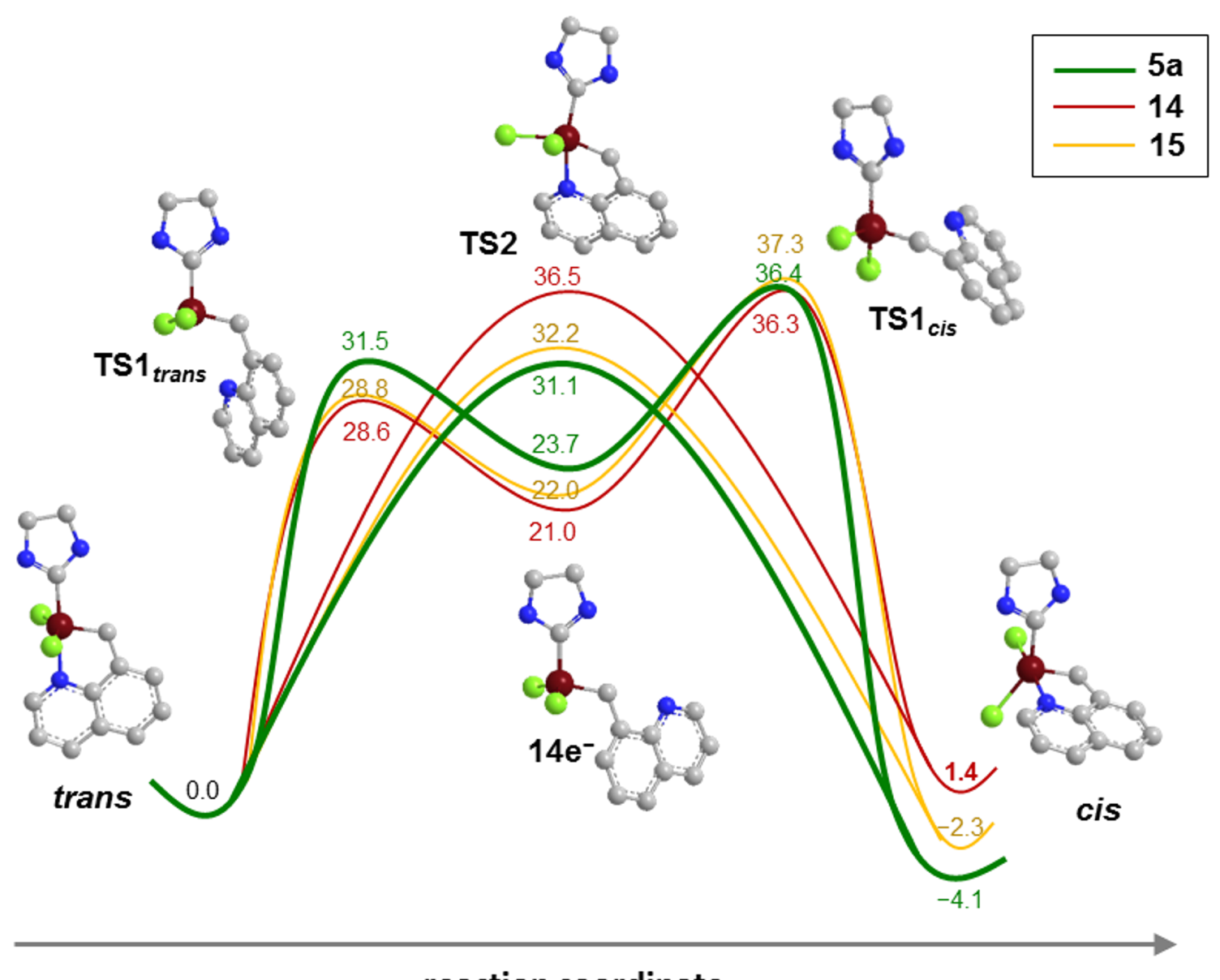

reaction coordinate

Figure 4: Energy profile of trans-cis isomerization, modelled in $\mathrm{CH}_{2} \mathrm{Cl}_{2},(\Delta E$ in $\mathrm{kcal} / \mathrm{mol})$. Geometry optimizations BP86//SVP, solvent effects included by single point calculations, using M06//TZVP. 


\section{Activity in RCM}

The consecutive step of the research was devoted to exploring the activity of the obtained complexes in metathesis reactions. The preliminary choice was to conduct ring-closing metathesis (RCM) of diethyl diallylmalonate (16, Scheme 4).

Initially examined conditions (DCM, rt) originate from the papers previously published by Grela's group on the subject [14,31]. Unfortunately, along with F. Hoffmann-La Roche AG researchers [32] we were unable to fully reproduce the aforementioned results. The complex was inert at ambient conditions and only tests at elevated temperatures $\left(80\right.$ or $\left.140{ }^{\circ} \mathrm{C}\right)$ revealed catalytic activity of $\mathbf{5 a}$. When substrate $\mathbf{1 6}$ was subjected to RCM in high temperature conditions, a complex mixture of products was obtained (Figure 5). Upon GC and GC-MS analysis, structures of compounds 17-19 were determined (cf. Supporting Information File 1).

The substituted complexes were inert in ambient conditions similarly to the parent complex. The experiments at elevated temperature (toluene, $80^{\circ} \mathrm{C}$ ) revealed that precatalysts $\mathbf{1 4}$ and $\mathbf{1 5}$ led to higher conversions than the unsubstituted version $\mathbf{5 a}$ What is more interesting, both complexes exhibit prolonged activity and similar overall activity under the studied conditions. An interesting observation is that reactions catalyzed with 14 and 15 gave predominantly the RCM product (compound 17) accompanied by a minor amount of a cycloisomerizationderived compound 19. It is worth noting, that even after heating at $80^{\circ} \mathrm{C}$ for $100 \mathrm{~h}$ the catalysts were still active, as can be assessed from the time/conversion plots (cf. Figure $5 \mathrm{a}$ and b). In contrast, the precatalyst $\mathbf{5 a}$ promoted predominantly cycloisomerization albeit conversion was poor (cf. Figure 5c). Because all transformations were very slow at $80^{\circ} \mathrm{C}$ the next series of test reactions was conducted at $140{ }^{\circ} \mathrm{C}$ in xylenes as the solvent (cf. Figure 5d-f). Electronically modified derivatives $\mathbf{1 4}$ and 15 promoted a faster transformation of $\mathbf{1 6}$. In the first $10 \mathrm{~min}$. about $90 \%$ of 16 was converted into about $80 \%$ cycloisomeriza- tion product 19 and about $12-16 \%$ RCM-product 17, thus the selectivity changed upon raising the temperature. In addition, a minor amount of the isomerized RCM-product $\mathbf{1 8}$ and isomerized diethyl diallylmalonate $\mathbf{2 0}$ were detected in the reaction mixture. After about $1 \mathrm{~h}$ reaction time, the composition of the reaction mixture remained virtually unchanged upon prolonged heating.

At this high temperature, the precatalyst trans-5a resulted in a complete conversion of $\mathbf{1 6}$ which gave more than $90 \%$ cycloisomerization product 19 in $8 \mathrm{~h}$. A small amount of isomerized diethyl diallylmalonate $\mathbf{2 0}$ and RCM-product $\mathbf{1 7}$ were also observed (cf. Figure 5f). Using cis-5a as the precatalyst resulted in similar results as can be seen in Figure 6. This is not especially peculiar as isomerization is conducted in the very same temperature range within less than 30 minutes meaning that the corresponding equilibrium is reached quickly.

Basing on the described experiments, it can be stated that precatalysts are thermally stable in the absence of oxygen and diethyl diallylmalonate at temperatures as high as $140^{\circ} \mathrm{C}$. Electronically modified precatalysts $\mathbf{1 4}$ and $\mathbf{1 5}$ initiate significantly faster than the parent precatalyst 5a and when employed in RCM of diethyl diallylmalonate at $80^{\circ} \mathrm{C}$, those complexes gave predominantly the RCM product $\mathbf{1 7}$ accompanied with minor amounts of the cycloisomerization product $\mathbf{1 9}$, while $\mathbf{5 a}$ released predominantly the cycloisomerization product $\mathbf{1 9}$.

Switching to $140{ }^{\circ} \mathrm{C}$ reaction temperature, all precatalysts released the cycloisomerization product $\mathbf{1 9}$ as the main product. These observations make again clear that the thermal stability of the precatalyst becomes irrelevant once it is in the presence of the substrate [33], because it is the thermal stability of the actual active species in the reaction mixture that governs the reaction outcome. In the present case, the methylidene complex formed during metathesis with the terminal olefin diethyl diallylmalonate is probably the most fragile species [32,34-36]. A

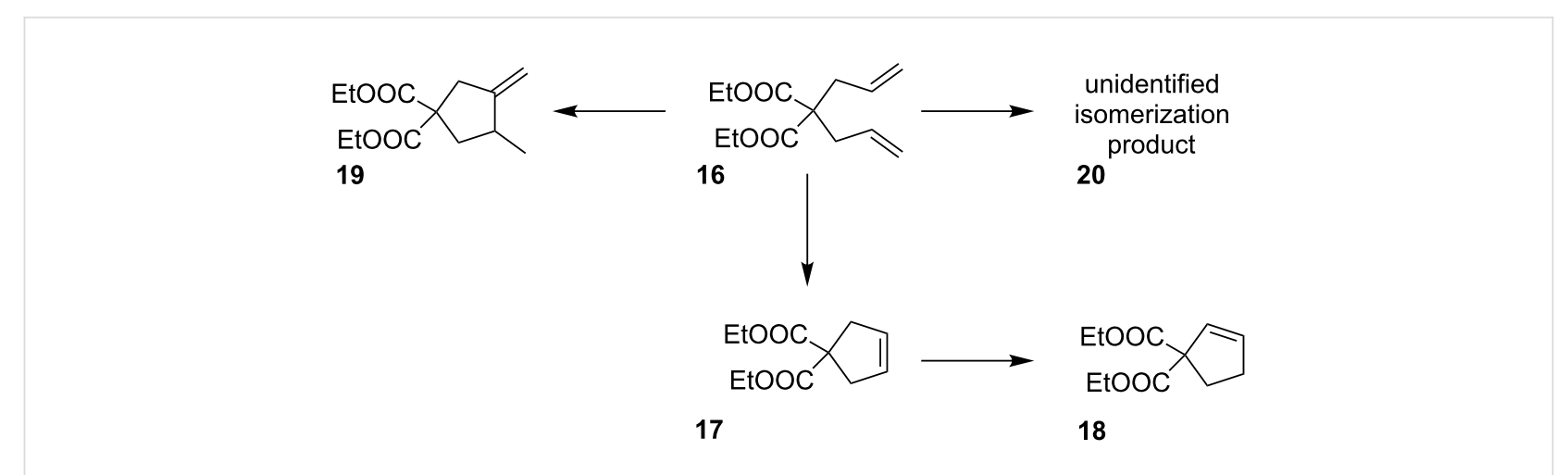

Scheme 4: Possible reaction pathways of 16 

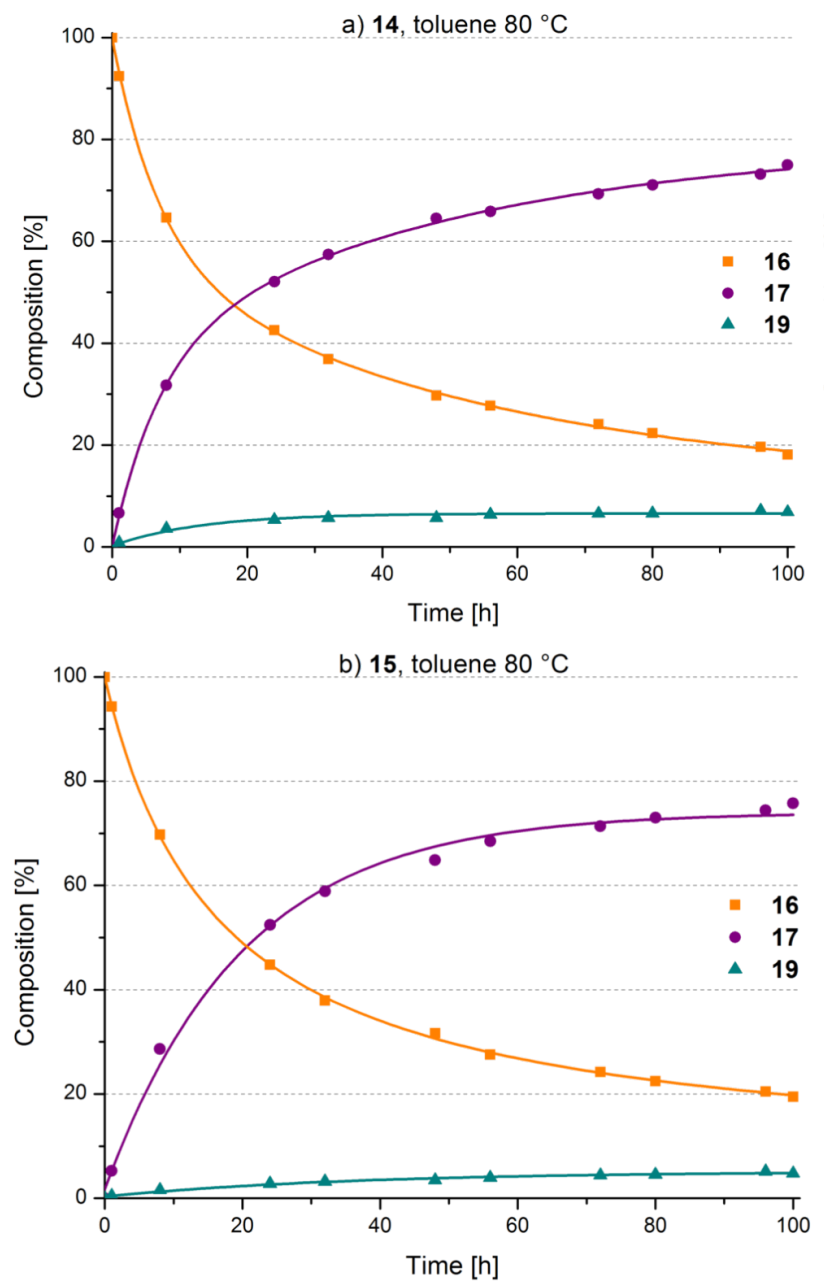

c) $5 \mathrm{a}$, toluene $80^{\circ} \mathrm{C}$

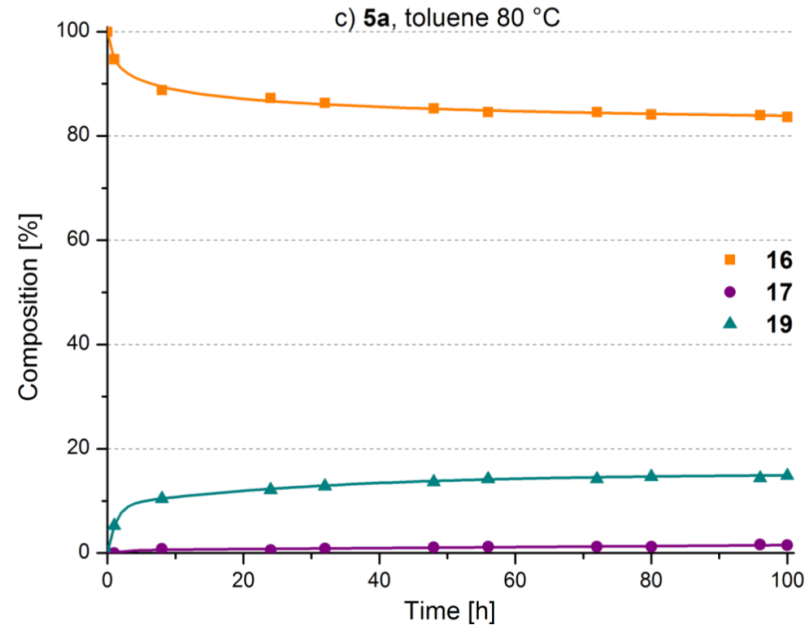

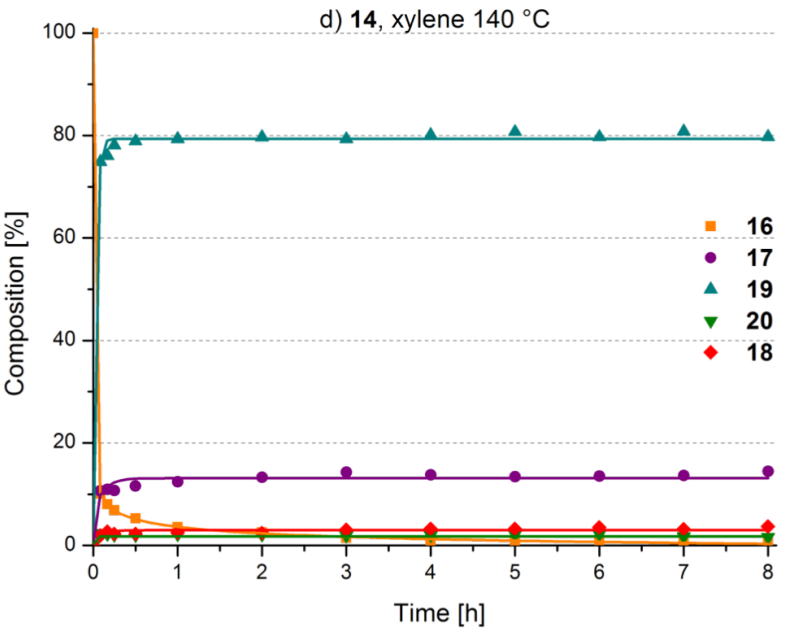

e) 15 , xylene $140^{\circ} \mathrm{C}$

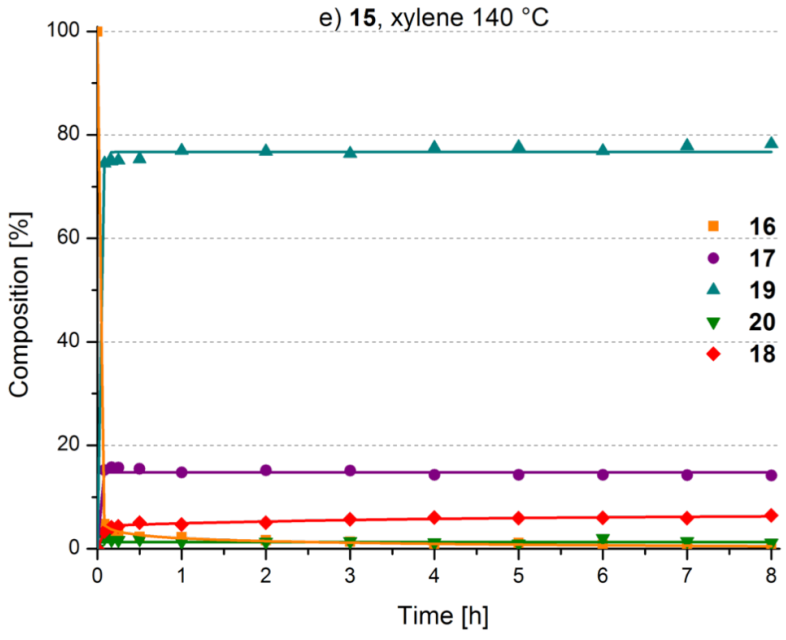

f) $5 \mathrm{a}$, xylene $1400^{\circ} \mathrm{C}$

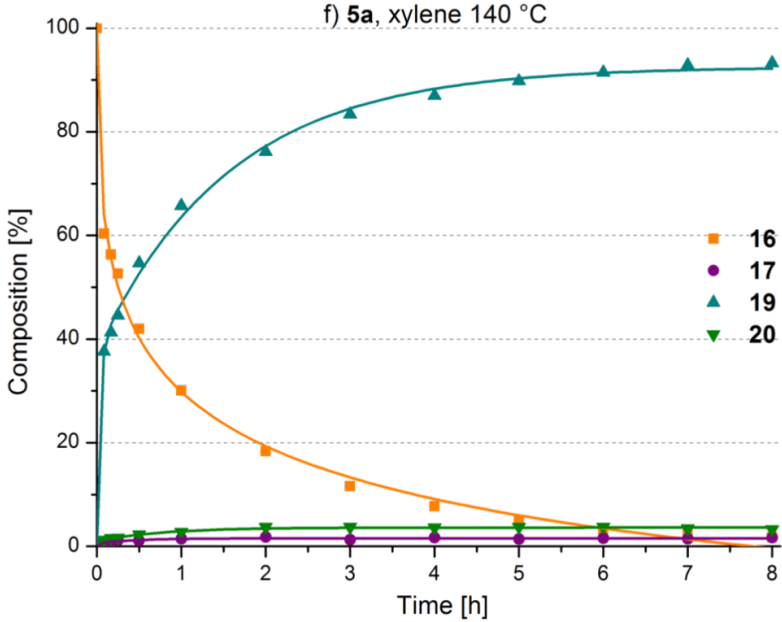

Figure 5: Time/conversion plots for the transformation of 16 catalyzed by $5 \mathrm{~mol} \%$ of the trans isomers of trans-5a, 14 and 15 . Lines are intended as visual aids.

recent work provides evidence that the catalytic species responsible for (cyclo)isomerization originates from decomposition of the methylidene [37]. Generally, the ability of olefin metathesis precatalysts to promote cycloisomerization [38] is known and has been widely researched both theoretically $[39,40]$ and experimentally [41-43]. Moreover, the methylidene species 


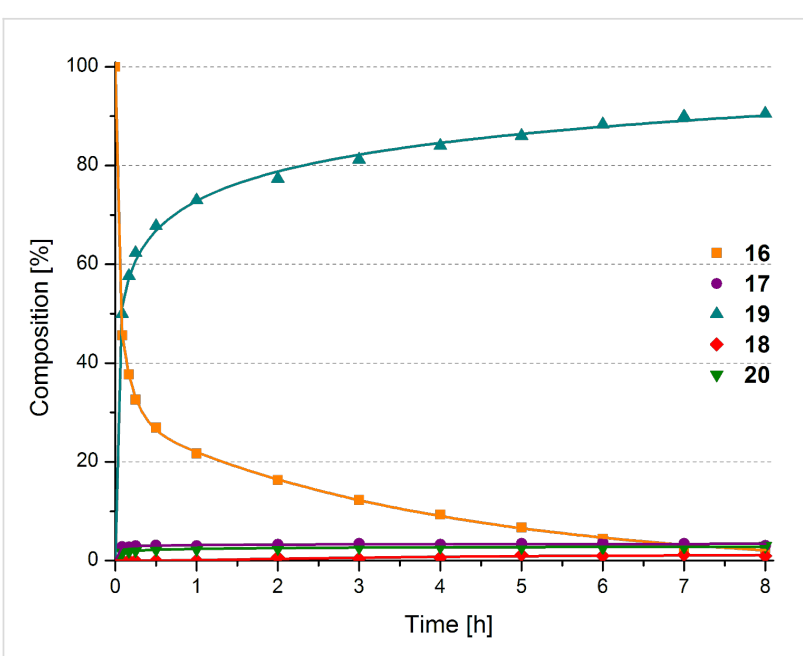

Figure 6: Composition of a reaction mixture after subjecting 16 to 5 mol \% cis-5a in xylene, $140{ }^{\circ} \mathrm{C}$. Lines are intended as visual aids.

alone are characterized by a certain degree of stability that is dramatically reduced in the presence of olefins, in particular, ethylene [38]. Accordingly, RCM reactions can be improved in terms of efficiency when ethylene is removed [44-46]. Based on these facts, the catalytic performance of the precatalysts 14 and 15 can be explained as follows: At $80^{\circ} \mathrm{C}$ the actual active species is slowly released and performs mainly metathesis with diethyl diallylmalonate (16) leading, amongst other species, to the methylidene complex [47]. The latter is moderately stable under these conditions and participates in the catalytic RCM cycle. A concurring decomposition reaction of the methylidene or another Ru-species is responsible for the cycloisomerization side reaction. Further, the latter species is not able to isomerize the educt or the RCM product. Upon increasing the temperature to $140{ }^{\circ} \mathrm{C}$, the said decomposition reaction is faster leading to the observed switch of reactivity in favor of the cycloisomerization pathway and isomerization of the educt as well as that of the product is observed. However, the results for 5a as the precatalyst make clear that the thermal stability of the methylidene is not the only factor governing the outcome of the studied reactions. If the stability of the methylidene were the only crucial factor in all cases, the product distributions from reactions with $\mathbf{5 a}$ would be similar to those from $\mathbf{1 4}$ and $\mathbf{1 5}$. This is definitely not the case. Therefore, it can be assumed that in case of 5a another, yet unknown decomposition reaction is responsible for the occurrence of the cycloisomerization reaction.

\section{Use as initiators in ROMP}

In the next step, compounds 5a, 14 and $\mathbf{1 5}$ were tested as initiators in ring-opening metathesis polymerization (ROMP). The active species in ROMP (i.e., the propagating species) can be considered more stable than the methylidene intermediate in RCM, particularly when norbornenes such as endo,exo-

bicyclo[2.2.1] hept-5-ene-2,3-dicarboxylic acid dimethyl ester (21) are polymerized (Figure 7) [48].

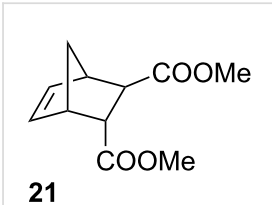

Figure 7: Monomers utilized in model ROMP reactions.

First, 300 equivalents of monomer 21 were polymerized with 1 equivalent initiator $(\mathbf{5 a}, \mathbf{1 4}$ or $\mathbf{1 5})$ at $110{ }^{\circ} \mathrm{C}$ in toluene $([\mathbf{2 1}]=0.1 \mathrm{M})$ for 2 days. Initiator $\mathbf{5 a}$ polymerized $90 \%$ of $\mathbf{2 1}$ and the corresponding polymer was characterized by a number average molecular weight $\left(M_{\mathrm{n}}\right)$ of $557.0 \mathrm{~kg} \cdot \mathrm{mol}^{-1}$ (polydispersity index, PDI $=1.9$ ) as examined by size exclusion chromatography (SEC) in THF against poly(styrene) standards. Initiator 15 gave $93 \%$ monomer-conversion and the resulting polymer exhibited a $M_{\mathrm{n}}$ of $516.0 \mathrm{~kg} \cdot \mathrm{mol}^{-1}(\mathrm{PDI}=2.2)$ and 14 gave the highest conversion $(98 \%)$ and the shortest polymer strands $\left(M_{\mathrm{n}}=326.7 \mathrm{~kg} \cdot \mathrm{mol}^{-1}\right.$; PDI $\left.=2.2\right)$.

The $M_{\mathrm{n}}$ values allow for an indirect relative assessment of the initiation efficacy [49-54], because they are proportional to the ratio of the propagation rate $\left(k_{\mathrm{p}}\right)$ and the initiation rate constant $\left(k_{\mathrm{i}}\right)$, provided that no secondary metathesis occurs. In this case, $M_{\mathrm{n}}$ is only dependent on $k_{\mathrm{i}}$, because in all cases the same propagating species occurs and $k_{\mathrm{p}}$ is the same. Accordingly, initiator 14 exhibits the highest initiation efficacy and initiator 5a the lowest. Analyzing these data as disclosed previously, a linear correlation between the $M_{\mathrm{n}}$ values and the difference between the calculated thermodynamic stabilities of the trans- and the cis-dichloro configured isomers $\left(\Delta E_{\text {trans }^{-} \text {-cis }}\right)$ can be established (Figure 8). This correlation suggests that the initiation efficacy is above all determined by the position of the trans-cis equilibrium which can be quickly reached at $110^{\circ} \mathrm{C}[29,55]$.

In the second step, the initiators were tested in neat monomer using simultaneous thermal analysis (STA) for monitoring the polymerizations. As the monomer, either endo,exobicyclo[2.2.1]hept-5-ene-2,3-dicarboxylic acid diethyl ester (22) or dicylcopentadiene (23) were used (cf. Figure 7). A distinctly changed initiation trend was observed under these reaction conditions. Initiator 5a started the polymerization at the lowest temperature (onset of the polymerization exotherm at approx. $60^{\circ} \mathrm{C}$; cf. Figure 9, left) while the highest latency was found for initiator 14 (onset at approx. $75^{\circ} \mathrm{C}$ ). While initiators 14 and 15 exhibited rather sharp exotherms for the polymerization of monomer 22, a much broader shape was found in the case of 5a. This shape can be explained by assuming, that the 


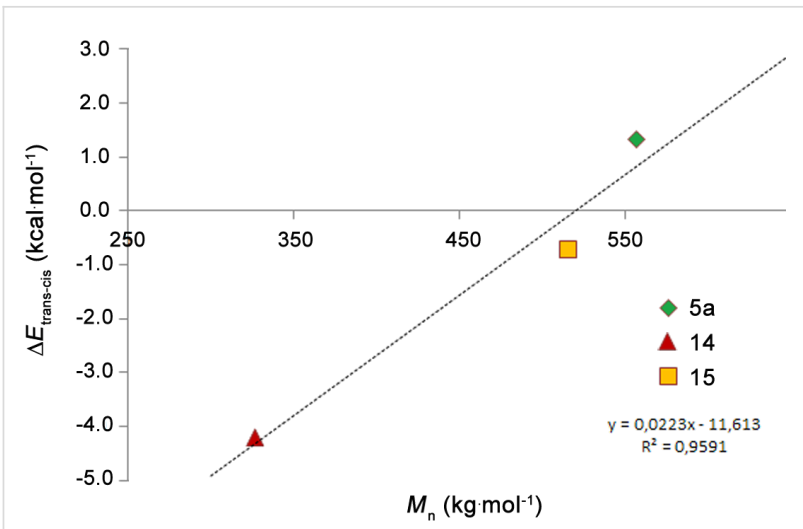

Figure 8: Number-average molecular weight $\left(M_{\mathrm{n}}\right)$ of poly-21 prepared with initiators 5a, 14 and $\mathbf{1 5}$ plotted against the theoretically determined difference of trans-cis energies (solvation model PCM, solvent toluene).

isomerization of trans-5a to $c i s-\mathbf{5 a}$ is a concurring reaction, thus slowing down the polymerization reaction. The reason for the unexpectedly, at first sight, delayed initiation of $\mathbf{1 4}$ and $\mathbf{1 5}$ can most probably be attributed to steric effects. It is known that a coordination at the free coordination site (trans to the carbene ligand) can activate the (pre-)catalyst by lowering the energy barrier TS1 $1_{\text {trans }}$ to reach the active 14-electron species $[14,56,57]$. As both substituents, the $\mathrm{CHO}$ and the $\mathrm{CN}$ group, sterically shield the vacant coordination site, it is easily conceivable that such substrate-induced activation is impeded.

This effect turned out to be of particular relevance when the polymerization of dicyclopentadiene is regarded. Because polymerizations were carried out in open reaction vessels, the retroDiels-Alder reaction of $\mathbf{2 3}$, releasing volatile cyclopentadiene, is a concurring reaction and responsible for the low(er) polymer yields and pronounced endothermic signals in the DSC traces (cf. Figure 9 right) [58]. While initiator 5a shows an appealing performance in polymerizing $\mathbf{2 3}$, the electronically modified congeners $\mathbf{1 4}$ and $\mathbf{1 5}$ are not particularly interesting for this application.

\section{Conclusion}

The present work introduced two ruthenium-based olefin metathesis catalysts/initiators featuring electronically modified quinoline-based chelating carbene ligands. Their reactivity in RCM and ROMP reactions was tested and results were set in comparison to those obtained with the parent compound, bearing the unsubstituted quinoline-based chelating carbene. The entire set of compounds is very stable at high temperatures up to $140{ }^{\circ} \mathrm{C}$ in the absence of oxygen and metathesis substrates. Electronic modification of the quinoline moiety changes the position of the trans-cis equilibrium as shown experimentally and theoretically. At the same time, electronic modification lowers the transition state energy for the generation of the catalytically active 14-electron species and increases the energy barrier for the transformation into the corresponding cis-dichloro isomers. Both effects translate into an enhanced activity in RCM at $80{ }^{\circ} \mathrm{C}$ when compared to the unmodified catalyst. In particular, the position of the trans-cis equilibrium is the most crucial factor governing the reactivity of the complexes. While electronically modified precatalysts which exist predominantly in trans-dichloro configuration gave mostly RCM and minor amounts of cycloisomerization product, the unmodified congener which preferentially exists in its cisdichloro isomer, shows a switched reactivity. The reactivity switch is most probably caused by different substrate-induced decomposition reactions being responsible for the occurrence of the cycloisomerization reaction, which are more important at higher temperatures of $140{ }^{\circ} \mathrm{C}$. In ROMP, again the position of the trans-cis equilibrium is the most crucial factor governing the initiation efficacy. Additionally, it has been shown, that steric effects of the substitution are responsible for an altered
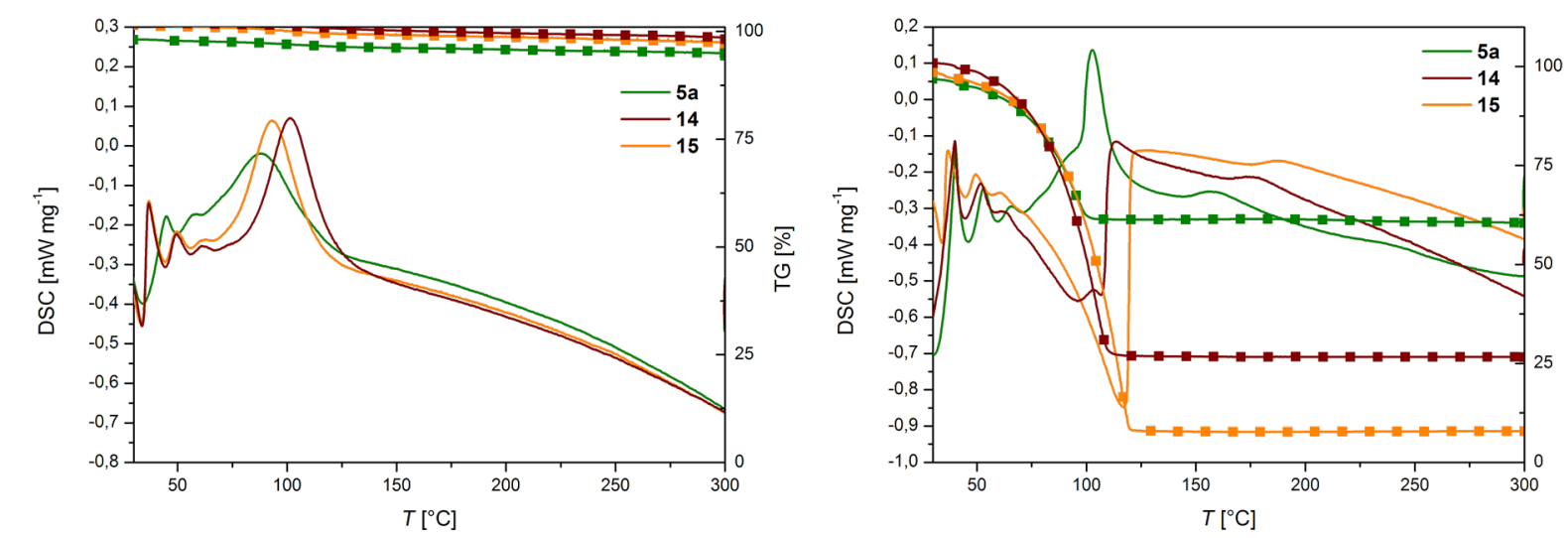

Figure 9: STA analysis of polymerization of 22 (left) and 23 (right), initiated by 5a, 14 and 15. Reaction conditions: [22]:[initiator] = 500 and [23]: [initiator] = 10000:1. Heating rate: $3 \mathrm{~K} / \mathrm{min}$. Big symbols: thermogravimetric analysis (TGA); no symbols: differential scanning calorimetry (DSC). 
order of initiation behavior when polymerizations are conducted in bulk.

\section{Experimental}

Preparation of 14 and 15 . Precursor complex $1(0.5 \mathrm{mmol}$, $475 \mathrm{mg})$ and the respective styrene derivative $(0.55 \mathrm{mmol})$ were put in a Schlenk tube under argon. Reagents were dissolved in anhydrous toluene $(25 \mathrm{~mL})$ and the reaction was heated at $80^{\circ} \mathrm{C}$ for about an hour. Then the solvent was evaporated and the mixture was purified by flash chromatography using eluents $c$-hexane/ethyl acetate 10:1 to $1: 1 \mathrm{v} / \mathrm{v}$. The solvent was evaporated. The product was then re-dissolved in dichloromethane and cold $n$-heptane was added to yield the product $\mathbf{1 4}$ as dark brown crystals $(0.37 \mathrm{mmol}, 242 \mathrm{mg}, 75 \%) .{ }^{1} \mathrm{H} \mathrm{NMR}\left(\mathrm{CD}_{2} \mathrm{Cl}_{2}\right)$ $\delta 2.41(\mathrm{~s}, 6 \mathrm{H}), 2.49(\mathrm{~s}, 12 \mathrm{H}), 4.16(\mathrm{~s}, 4 \mathrm{H}), 7.07(\mathrm{~s}, 4 \mathrm{H})$, $7.48-7.53(\mathrm{~m}, 2 \mathrm{H}), 7.72(\mathrm{dd}, J=0.9,7.2 \mathrm{~Hz}, 1 \mathrm{H}), 8.24(\mathrm{dd}, J=$ $0.9,8.3 \mathrm{~Hz}, 1 \mathrm{H}), 8.33(\mathrm{~d}, J=8.5 \mathrm{~Hz}, 1 \mathrm{H}), 16.95$ (s, 1H) ppm; ${ }^{13} \mathrm{C}$ NMR $\left(\mathrm{CD}_{2} \mathrm{Cl}_{2}\right) \delta 19.0,20.9,51.8,116.1,117.5,122.6$, 128.1, 129.4, 129.7, 133.9, 134.0, 134.6, 136.2, 138.3, 138.9, 146.8, 155.6, 209.4, 285.5 ppm; IR (KBr) v: 3320, 3042, 3004, 2949, 2912, 2855, 2837, 2810, 2237, 1959, 1704, 1682, 1601, 1586, 1556, 1478, 1454, 1445, 1427, 1418, 1398, 1378, 1326, $1315,1289,1256,1217,1199,1176,1148,1133,1102,1061$, 1036, 1014, 985, 966, 930, 911, 879, 848, 822, 813, 792, 777, 752, 734, 721, 701, 653, 643, 622, 580, 533, 498, 428, 415 $\mathrm{cm}^{-1}$; HRMS (ESI) $(\mathrm{m} / \mathrm{z}):[\mathrm{M}] \mathrm{calcd}, 644.1048$; found, 644.1041 .

Complex 15 was prepared analogously yielding dark brown crystals $(0.43 \mathrm{mmol}, 280 \mathrm{mg}, 86 \%) .{ }^{1} \mathrm{H}$ NMR $\left(\mathrm{CD}_{2} \mathrm{Cl}_{2}\right) \delta$ 2.43-2.55 (m, 16H), $4.19(\mathrm{~s}, 4 \mathrm{H}), 7.11(\mathrm{~s}, 4 \mathrm{H}), 7.48-7.55(\mathrm{~m}$, $1 \mathrm{H}), 7.72(\mathrm{dd}, J=0.9,7.2 \mathrm{~Hz}, 1 \mathrm{H}), 7.78(\mathrm{~d}, J=8.5 \mathrm{~Hz}, 1 \mathrm{H})$, $8.28(\mathrm{dd}, J=0.9,8.2 \mathrm{~Hz}, 1 \mathrm{H}), 8.35(\mathrm{~d}, J=8.3 \mathrm{~Hz}, 1 \mathrm{H}), 8.96(\mathrm{~d}$, $J=0.6, \mathrm{~Hz}, 1 \mathrm{H}), 17.11(\mathrm{~s}, 1 \mathrm{H}) \mathrm{ppm} ;{ }^{13} \mathrm{C} \mathrm{NMR}\left(\mathrm{CD}_{2} \mathrm{Cl}_{2}\right) \delta$ 19.1, 20.9, 51.6, 117.0, 122.8, 129.2, 130.8, 133.4, 134.3, 136.0, $138.9,139.0,145.9,152.2,156.3,190.0,210.6,288.2$ ppm; IR (KBr) v: 3003, 2952, 2912, 2854, 2734, 2232, 1950, 1734, 1694, 1605, 1584, 1551, 1480, 1419, 1401, 1379, 1319, 1294, 1261, 1222, 1174, 1154, 1138, 1092, 1036, 987, 929, 910, 887, $846,813,794,775,732,699,680,644,591,578,535,419$ $\mathrm{cm}^{-1}$; HRMS (ESI) $(\mathrm{m} / \mathrm{z}):[\mathrm{M}-2 \mathrm{Cl}+\mathrm{H}]^{+}$calcd, 578.1745; found, 578.1732 .

\section{Supporting Information}

\section{Supporting Information File 1}

Full experimental section along with all the synthetic procedures and analytical data of the obtained compounds. [http://www.beilstein-journals.org/bjoc/content/ supplementary/1860-5397-11-158-S1.pdf]

\section{Acknowledgements}

KŻ thanks for the „Diamond Grant” research project financed from the governmental funds for science for 2012-2015. Dr. M. Kędziorek is acknowledged for providing the precursor of $\mathbf{5 a}$. EP gratefully acknowledges to "Chemical Monthly" for financial support of this work. Authors acknowledge for the WTZ PL10/2014 cooperation.

\section{References}

1. Grela, K., Ed. Olefin Metathesis: Theory and Practice; John Wiley \& Sons, Inc.: Hoboken, 2014.

2. Bieniek, M.; Michrowska, A.; Usanov, D. L.; Grela, K. Chem. - Eur. J. 2008, 14, 806-818. doi:10.1002/chem.200701340

3. Schrock, R. R.; Hoveyda, A. H. Angew. Chem., Int. Ed. 2003, 42, 4592-4633. doi:10.1002/anie.200300576

4. Leitgeb, A.; Wappel, J.; Slugovc, C. Polymer 2010, 51, 2927-2946. doi:10.1016/j.polymer.2010.05.002

5. Vougioukalakis, G. C.; Grubbs, R. H. Chem. Rev. 2010, 110, 1746-1787. doi:10.1021/cr9002424

6. Samojłowicz, C.; Bieniek, M.; Grela, K. Chem. Rev. 2009, 109, 3708-3742. doi:10.1021/cr800524f

7. Garber, B.; Kingsbury, J. S.; Gray, B. L.; Hoveyda, A. H. J. Am. Chem. Soc. 2000, 122, 8168-8179. doi:10.1021/ja001179g

8. Vidavsky, Y.; Anaby, A.; Lemcoff, N. G. Dalton Trans. 2012, 41, 32-43. doi:10.1039/C1DT11404B

9. Ben-Asuly, A.; Tzur, E.; Diesendruck, C. E.; Sigalov, M.; Goldberg, I.; Lemcoff, N. G. Organometallics 2008, 27, 811-813. doi:10.1021/om701180z

10. Szadkowska, A.; Makal, A.; Woźniak, K.; Kadyrov, R.; Grela, K. Organometallics 2009, 28, 2693-2700. doi:10.1021/om801183g

11. Szadkowska, A.; Żukowska, K.; Pazio, A. E.; Woźniak, K.; Kadyrov, R.; Grela, K. Organometallics 2011, 30, 1130-1138. doi:10.1021/om101129b

12. van der Schaaf, P. A.; Kolly, R.; Kirner, H.-J.; Rime, F.; Mühlebach, A.; Hafner, A. J. Organomet. Chem. 2000, 606, 65-74. doi:10.1016/S0022-328X(00)00289-8

13. Szadkowska, A.; Gstrein, X.; Burtscher, D.; Jarzembska, K.; Woźniak, K.; Slugovc, C.; Grela, K. Organometallics 2010, 29 , 117-124. doi:10.1021/om900857w

14. Barbasiewicz, M.; Szadkowska, A.; Bujok, R.; Grela, K. Organometallics 2006, 25, 3599-3604. doi:10.1021/om060091u

15. Peeck, L. H.; Savka, R. D.; Plenio, H. Chem. - Eur. J. 2012, 18, 12845-12853. doi:10.1002/chem.201201010

16. Diesendruck, C. E.; Tzur, E.; Ben-Asuly, A.; Goldberg, I.; Straub, B. F.; Lemcoff, N. G. Inorg. Chem. 2009, 48, 10819-10825. doi:10.1021/ic901444c

17. Żukowska, K.; Szadkowska, A.; Pazio, A. E.; Woźniak, K.; Grela, K. Organometallics 2012, 31, 462-469. doi:10.1021/om2011062

18. Hejl, A.; Day, M. W.; Grubbs, R. H. Organometallics 2006, 25, 6149-6154. doi:10.1021/om060620u

19. Slugovc, C.; Burtscher, D.; Stelzer, F.; Mereiter, K. Organometallics 2005, 24, 2255-2258. doi:10.1021/om050141f

20. De Clercq, B.; Verpoort, F. Adv. Synth. Catal. 2002, 344, 639-648.

21. Jordaan, M.; Vosloo, H. C. M. Adv. Synth. Catal. 2007, 349, 184-192. doi:10.1002/adsc.200600474

22. Slugovc, C.; Perner, B.; Stelzer, F.; Mereiter, K. Organometallics 2004, 23, 3622-3626. doi:10.1021/om049877n 
23. Poater, A.; Ragone, F.; Correa, A.; Szadkowska, A.; Barbasiewicz, M.; Grela, K.; Cavallo, L. Chem. - Eur. J. 2010, 16, 14354-14364. doi:10.1002/chem.201001849

24. Pump, E.; Cavallo, L.; Slugovc, C. Monatsh. Chem. 2015, 146, 1131-1141. doi:10.1007/s00706-015-1433-8

25. Ung, T.; Hejl, A.; Grubbs, R. H.; Schrodi, Y. Organometallics 2004, 23, 5399-5401. doi:10.1021/om0493210

26. Guidone, S.; Songis, O.; Nahra, F.; Cazin, C. S. J. ACS Catal. 2015, 5, 2697-2701. doi:10.1021/acscatal.5b00197

27. Aharoni, A.; Vidavsky, Y.; Diesendruck, C. E.; Ben-Asuly, A.; Goldberg, I.; Lemcoff, N. G. Organometallics 2011, 30, 1607-1615 doi:10.1021/om1011402

28. Zaja, M.; Connon, S. J.; Dunne, A. M.; Rivard, M.; Buschmann, N.; Jiricek, J.; Blechert, S. Tetrahedron 2003, 59, 6545-6558. doi:10.1016/S0040-4020(03)01029-9

29. Michrowska, A.; Bujok, R.; Harutyunyan, S.; Sashuk, V.; Dolgonos, G.; Grela, K. J. Am. Chem. Soc. 2004, 126, 9318-9325. doi:10.1021/ja048794v

30. Pump, E.; Poater, A.; Zirngast, M.; Torvisco, A.; Fischer, R.; Cavallo, L.; Slugovc, C. Organometallics 2014, 33, 2806-2813. doi:10.1021/om500315t

31. Grela, K.; Barbasiewicz, M.; Szadkowska, A. Complexes of Ruthenium and osmium, method of production thereof and use thereof as (pre)catalysts of the metathesis reaction. WO Patent WO140954, Dec 13, 2007

32. Puentener, K.; Scalone, M. New ruthenium complexes as catalysts for metathesis reactions. WO Patent WO2008000644, Jan 3, 2008.

33. Nelson, D. J.; Manzini, S.; Urbina-Blanco, C. A.; Nolan, S. P. Chem. Commun. 2014, 50, 10355-10375. doi:10.1039/C4CC02515F

34. Lummiss, J. A. M.; Beach, N. J.; Smith, J. C.; Fogg, D. E. Catal. Sci. Technol. 2012, 2, 1630-1632. doi:10.1039/C2CY20213A

35. Sanford, M. S.; Love, J. A.; Grubbs, R. H. J. Am. Chem. Soc. 2001, 123, 6543-6554. doi:10.1021/ja010624k

36. Hong, S. H.; Wenzel, A. G.; Salguero, T. T.; Day, M. W.; Grubbs, R. H. J. Am. Chem. Soc. 2007, 129, 7961-7968. doi:10.1021/ja0713577

37. Nelson, D. J.; Percy, J. M. Dalton Trans. 2014, 43, 4674-4679. doi:10.1039/C4DT00007B

38. Lloyd-Jones, G. C. Org. Biomol. Chem. 2003, 1, 215-236. doi:10.1039/B209175P

39. van Rensburg, W. J.; Steynberg, P. J.; Meyer, W. H.; Kirk, M. M.; Forman, G. S. J. Am. Chem. Soc. 2004, 126, 14332-14333. doi:10.1021/ja0453174

40. van Rensburg, W. J.; Steynberg, P. J.; Kirk, M. M.; Meyer, W. H.; Forman, G. S. J. Organomet. Chem. 2006, 691, 5312-5325. doi:10.1016/j.jorganchem.2006.08.075

41. Bourgeois, D.; Pancrazi, A.; Nolan, S. P.; Prunet, J. J. Organomet. Chem. 2002, 643-644, 247-252. doi:10.1016/S0022-328X(01)01269-4

42. Lehman, S. E., Jr.; Schwendeman, J. E.; O'Donnel, P. M.; Wagener, K. B. Inorg. Chim. Acta 2003, 345, 190-198. doi:10.1016/S0020-1693(02)01307-5

43. Feng, C.; Wang, X.; Wang, B.-Q.; Zhao, K.-Q.; Hu, P.; Shi, Z.-J. Chem. Commun. 2012, 48, 356-358. doi:10.1039/C1CC15835J

44. Lysenko, Z.; Maughon, B. R.; Mokhtar-Zadeh, T.; Tulchinsky, M. L. J. Organomet. Chem. 2006, 691, 5197-5203. doi:10.1016/j.jorganchem.2006.08.031

45. Monfette, S.; Eyholzer, M.; Roberge, D. M.; Fogg, D. E. Chem. - Eur. J. 2010, 16, 11720-11725. doi:10.1002/chem.201001210

46. Skowerski, K.; Czarnocki, S. J.; Knapkiewicz, P. ChemSusChem 2014, 7, 536-542. doi:10.1002/cssc.201300829
47. Stewart, I. C.; Keitz, B. K.; Kuhn, K. M.; Thomas, R. M.; Grubbs, R. H. J. Am. Chem. Soc. 2010, 132, 8534-8535. doi:10.1021/ja1029045

48. Slugovc, C.; Demel, S.; Riegler, S.; Hobisch, J.; Stelzer, F. Macromol. Rapid Commun. 2004, 25, 475-480. doi:10.1002/marc.200300196

49. Kozłowska, A.; Dranka, M.; Zachara, J.; Pump, E.; Slugovc, C.; Skowerski, K.; Grela, K. Chem. - Eur. J. 2014, 20, 14120-14125. doi:10.1002/chem.201403580

50. Urbina-Blanco, C. A.; Bantreil, X.; Wappel, J.; Schmid, T. E.; Slawin, A. M. Z.; Slugovc, C.; Cazin, C. S. J. Organometallics 2013, 32, 6240-6247. doi:10.1021/om4004362

51. Pump, E.; Fischer, R. C.; Slugovc, C. Organometallics 2012, 31 , 6972-6979. doi:10.1021/om300785t

52. Urbina-Blanco, C. A.; Leitgeb, A.; Slugovc, C.; Bantreil, X.; Clavier, H.; Slawin, A. M. Z.; Nolan, S. P. Chem. - Eur. J. 2011, 17, 5045-5053. doi:10.1002/chem.201003082

53. Broggi, J.; Urbina-Blanco, C. A.; Clavier, H.; Leitgeb, A.; Slugovc, C.; Slawin, A. M. Z.; Nolan, S. P. Chem. - Eur. J. 2010, 16, 9215-9225. doi:10.1002/chem.201000659

54. Strasser, S.; Pump, E.; Fischer, R. C.; Slugovc, C. Monatsh. Chem. 2015, 146, 1143-1151. doi:10.1007/s00706-015-1484-x

55. Diesendruck, C. E.; Vidavsky, V.; Ben-Asuly, A.; Lemcoff, N. G. J. Polym. Sci., Part A: Polym. Chem. 2009, 47, 4209-4213. doi:10.1002/pola.23476

56. Żukowska, K.; Szadkowska, A.; Trzaskowski, B.; Pazio, A.; Pączek, Ł.; Woźniak, K.; Grela, K. Organometallics 2013, 32, 2192-2198. doi:10.1021/om400064c

57. Trzaskowski, B.; Grela, K. Organometallics 2013, 32, 3625-3630. doi:10.1021/om400233s

58. Leitgeb, A.; Wappel, J.; Urbina-Blanco, C. A.; Strasser, S.; Wappl, C.; Cazin, C. S. J.; Slugovc, C. Monatsh. Chem. 2014, 145, 1513-1517. doi:10.1007/s00706-014-1249-y

\section{License and Terms}

This is an Open Access article under the terms of the Creative Commons Attribution License (http://creativecommons.org/licenses/by/2.0), which permits unrestricted use, distribution, and reproduction in any medium, provided the original work is properly cited.

The license is subject to the Beilstein Journal of Organic Chemistry terms and conditions:

(http://www.beilstein-journals.org/bjoc)

The definitive version of this article is the electronic one which can be found at: $\underline{\text { doi: } 10.3762 / \text { bjoc. } 11.158}$ 